\title{
Brown rice, selenium yeast and $\alpha$-tocopherol acetate in chicken's diet: effects on meat quality
}

\section{Arroz integral, seleno-levedura e acetato de alfa-tocoferol na dieta de frangos de corte: efeitos sobre a qualidade da carne}

\author{
Aline Arassiana Piccini Roll ${ }^{1 *}$; Edenilse Gopinger ${ }^{1}$; Martha Lopes Schuch de \\ Castro $^{1}$; Jorge Schafhäuser Junior ${ }^{2}$; Victor Fernando Büttow Rollis; Fernando Rutz ${ }^{3}$
}

\begin{abstract}
The effects of diet supplementation with $\alpha$-tocopherol acetate (VE) and selenium yeast (SeL) on the water holding capacity (WHC), cooking weight loss (CL), drip loss (DL), $\mathrm{pH}$, colour and selenium concentration of the breast of chickens fed diets based on corn or brown rice were studied. From 21 days of age, a total of 200 birds were housed in 38 floor pens (experimental unit) in a randomised $2^{3}$ factorial arrangement. The levels of supplementation were VE ( 0 and $200 \mathrm{mg} / \mathrm{kg})$, organic selenium $(0$ and 0.3 ppm) and two diets (100\% corn and $100 \%$ brown rice) in a total of eight treatments: T1) corn +0 SeL + $0 \mathrm{VE}$ (control); T2) corn + $200 \mathrm{mg} / \mathrm{kg} \mathrm{VE}+0 \mathrm{SeL}$; T3) corn + $0 \mathrm{VE}+0.3 \mathrm{ppm} \mathrm{SeL}$; T4) corn + 200 $\mathrm{mg} / \mathrm{kg} \mathrm{VE}+0.3 \mathrm{ppm}$ SeL; T5) brown rice + $0 \mathrm{VE}+0 \mathrm{SeL}$; T6) brown rice + $200 \mathrm{mg} / \mathrm{kg} \mathrm{VE} \mathrm{+} 0$ SeL; T7) brown rice $+0 \mathrm{VE}+0.3 \mathrm{ppm} \mathrm{SeL}$; T8) brown rice $+200 \mathrm{mg} / \mathrm{kg} \mathrm{VE}+0.3 \mathrm{ppm} \mathrm{SeL}$. The concentration of selenium in the breast increased with VE supplementation in the $\operatorname{diet}(\mathrm{P}<0.001)$. However, a positive interaction between VE and SeL on selenium concentration in the meat was found $(\mathrm{P}=0.06)$. A better WHC with the inclusion of SeL and VE was found only in the rice-based diets. The replacement of corn by brown rice decreased $(\mathrm{P}<0.05)$ the yellowness of the meat. CL and DL were not significantly affected by the treatments. Broilers fed with SeL supplemented diets showed a higher $\mathrm{pH}$ in the breast than diets without supplementation. In conclusion, the interaction between VE and SeL increased selenium in meat but improved WHC only in rice-based diets. The replacement of corn by brown rice decreased the yellowness of chicken breast meat.
\end{abstract}

Key words: Colour. Cooking weight loss. Drip loss. pH. Water retention capacity.

\section{Resumo}

Foram estudados os efeitos da suplementação com acetato de alfa-tocoferol (VE) e seleno-levedura (SeL) Sel-Plex, Alltech ${ }^{\circledR}$ Inc, sobre o pH, a capacidade de retenção de água (CRA), perdas por cocção (PC), perdas por gotejamento (PG), cor do músculo e a concentração de selênio no peito de frangos alimentados com dietas a base de milho ou arroz. A partir de 21 dias de idade 200 frangos de corte Cobb foram alojados em 38 boxes (unidade experimental) num delineamento casualizado num arranjo fatorial $2 \times 2 \times 2$ em que foram fixados os níveis de suplementação "on top" de VE ( 0 e $200 \mathrm{mg} / \mathrm{kg}$ ), SeL (0 e 0,3 ppm) e dois ingredientes da dieta ( $100 \%$ milho e $100 \%$ arroz integral) totalizando oito tratamentos: T1) milho + 0SeL + 0VE (controle); T2) milho + 200mg/kg VE + 0SeL; T3) milho + 0VE + 0,3ppm SeL; T4) $\mathrm{milho}+200 \mathrm{mg} / \mathrm{kg} \mathrm{VE}+0,3 \mathrm{ppm} \mathrm{SeL} ; \mathrm{T} 5)$ arroz + 0VE +0SeL; T6) arroz + 200mg/kg VE + 0SeL;

\footnotetext{
${ }^{1}$ Discentes, Programa de Pós-Graduação em Zootecnia, Departamento de Zootecnia, UFPel, Campus Capão do Leão, Pelotas, RS, Brasil.E-mail: apiroll@yahoo.es; edezoo@yahoo.com.br; marthascastro@hotmail.com

2 Pesquisador, EMBRAPA-CPACT, Monte Bonito, Pelotas, RS, Brasil. E-mail: jorge.junior@embrapa.br

3 Profs., Programa de Pós-Graduação em Zootecnia, Departamento de Zootecnia, UFPel, Campus Capão do Leão, Pelotas, Brasil. E-mail: roll2@hotmail.com; frutz@alltech.com

* Author for correspondence
} 
T7) arroz + 0VE + 0,3ppm SeL; T8) arroz + 200mg/kg VE + 0,3ppm SeL. A quantidade de selênio no peito foi maior $(\mathrm{P}<0,0001)$ com a inclusão de $200 \mathrm{mg} / \mathrm{kg}$ de $\mathrm{VE}$, em comparação com os demais tratamentos. Entretanto, observou-se uma interação positiva entre VE e SeL na dieta sobre a quantidade de selênio recuperada na carne $(P=0,06)$. Foi encontrada melhor CRA com a inclusão de SeL e VE em dietas a base de arroz. A substituição do milho por arroz nas dietas reduziu a cor amarela na carne $(\mathrm{P}<0,05)$. PC e PG não foram significativamente afetadas pelos tratamentos. $\mathrm{O} \mathrm{pH}$ da carne do peito foi significativamente mais elevado nas aves recebendo dietas suplementadas de SeL. Em conclusão, a interação entre VE e SeL aumenta o selênio na carne, porém, melhorando a CRA somente em dietas a base de arroz. A substituição de milho por arroz integral reduz a intensidade da coloração amarela da carne do peito de frangos.

Palavras-chave: Cor. perdas por cocção. Perdas por gotejamento. Ph. Capacidade de retenção de água.

\section{Introduction}

Among cereals, corn is the main, energy concentrated ingredient used in animal diets in Brazil, with $69 \%$ of the total production designated for this purpose. However, there is a growing demand to direct this cereal toward others uses, such as biodiesel production or human food consumption, to raise its market price (SCHEIBLER et al., 2015).

The consumption of biodiesel in Brazil is a growing trend. On 23rd March 2015, a Brazilian senate law 613/2015 was approved that aims to use higher biodiesel blends in petroleum diesel on engines and vehicles (SENADO FEDERAL PROJETO DE LEI DO SENADO, 2015). This law mandates the progressive inclusion of biodiesel blends from $8 \%$ in 2016 to 9 and $10 \%$ after a subsequent 180 and 360 days, respectively. The law also requires the addition of $20 \% \mathrm{v} / \mathrm{v}$ biodiesel to petroleum diesel used in public transport in cities with over 500,000 inhabitants.

Among the main raw materials used for biodiesel production, are soybean oil, canola oil, palm oil and corn oil. The use of corn to produce ethanol can further restrict its availability for animal nutrition. Recently, the eminent installation of a plant for largescale ethanol production from corn in Lucas do Rio Verde, Mato Grosso State, Brazil, was announced, with the capacity to produce 60 million gallons of ethanol per annum (SUMMIT AGRICULTURAL GROUP, 2016).

Given the latest release to use rice production surplus foranimalfeed, itisnecessary thatnutritionists and researchers understand its effects on animal production and meat quality. Rice is a cereal that can be influenced by the time of year and economic conjectures, with its purchase cost often decreased. Whilst by-products of the rice industry, like broken rice and defatted rice bran, are commonly used for animal diet formulations (KIEFER; QUADROS, 2006), the same is not true for integral dehulled brown rice. Brown rice contains a significant lipid content. Lipid oxidation is the main chain reaction involving free radical formation that can change and impair the organoleptic characteristics of meat (COMINETTI et al., 2011). It is known that fatty acids, which typically comprise the diets of animals intended for consumption, are transferred to the final product that reaches the consumer (ROLL et al., 2016). The oxidation of muscle pigments promotes colour deterioration that affects the visual acceptability of fresh meat. A preventive treatment is the supplementation of animal diets with antioxidative compounds (MORRISSEY et al., 1994), like vitamin E (VE) and selenium (Se) that relate directly to the meat quality (MAHAN; KIM, 1999).

$\alpha$-Tocopherol, the most biologically active form of VE, can reduce the colour degradation by decreasing myoglobin oxidation (FAUSTMAN et al., 1998), neutralising free radicals in the cellular membranes, and protecting the phospholipid-rich fraction in subcellular membranes where lipid oxidation is initiated (BARROETA et al., 2002). This process improves the quality of meat products and increases the VE concentration in the tissues 
(AJUYAH et al., 1993; BUCKLEY et al., 1995). Under refrigerated or frozen conditions, VE can reduce the colour and flavour losses during meat storage (MORRISSEY et al., 1998; BOU et al., 2009).

The organic form of selenium (SeL) has also been recognised and used by the poultry industry as a supplement to improve oxidative stability and final product quality. SeL can enhance the protective effect of VE against oxidation by increasing glutathione peroxidase (GPx) action and glutathione concentration (ZIAEI; POUR, 2013), an important enzyme in destroying hydroperoxide and lipid hydroperoxides (COMINETTI et al., 2011).

With regard to the organoleptic characteristics of meat, colour, may be regarded as the most important factor influencing consumer choice (ZEOLA et al., 2007). Meat colour is influenced by several factors, among which, the presence of carotenoids in the fed, stimulates myoglobin levels in the muscle (MORENO et al., 2008).

The general aspect of the product at the time of purchase or at the time of preparation, highlights the importance of assessing the water holding capacity (WHC) because it influences the appearance of the meat before cooking, its behaviour during preparation, and juiciness during mastication (PARDI et al., 2001; LAWRIE, 2005; MORENO et al., 2008). Feeding animals with diets containing high levels of protein increases the WHC of the meat (SAÑUDO et al., 1998), probably due to the presence of fat in the carcass (SILVA SOBRINHO, 2001). The WHC in muscle structures influences the cooking weight loss (CWL), which is a measure of quality associated with meat yield at the time of consumption (MONTE et al., 2012).

There is little scientific information on the use of rice as chicken feed in poultry production. Furthermore, the results available in the literature concerning the benefits of SeL and VE to animals and their products, are contradictory. In this context, the present study aimed to evaluate the effect of supplementation with VE and SeL in corn- and brown rice-based diets on meat quality characteristics, such as $\mathrm{pH}, \mathrm{WHC}$, cooking weight loss (CL), drip loss (DL), colour, and quantification of Se in broiler breast muscle.

\section{Material and Methods}

This study was performed at the Professor Renato Rodrigues Peixoto poultry facilities, of the animal science department, FAEM/ UFPEL. The study was run according to the ethical standards established by the Experimental Ethics Committee (CEEA), Universidade Federal de Pelotas-UFPel, Brazil, under process number 23110.008586/201251.

\section{Diets and experimental design}

From 21-42 days of age, a total of 200 Cobb broilers were fed eight experimental diets in a randomised $2^{3}$ factorial arrangement with five repetitions of five birds (three males and two females) per experimental unit.

The basal diets contained $0.39 \mathrm{mg} / \mathrm{kg} \mathrm{Se}$ and $15.6 \mathrm{mg} / \mathrm{kg} \mathrm{VE}$, which were considered appropriate to meet the minimum requirements for broilers in accordance with the National Research Council (NRC, 1994). The diets were formulated with two SeL supplementation levels ( 0 and $0.3 \mathrm{ppm}$ from selenium yeast, Sel-Plex, Inc. Alltech $\left.{ }^{\circledR}\right)$; and two VE supplementation levels (0 and $200 \mathrm{mg} / \mathrm{kg}$ of $\alpha$-tocopherol acetate) in corn- and brown rice-based diets consisting of eight treatments: T1) corn +0 $\mathrm{SeL}+0 \mathrm{VE}$ (control); T2) corn $+200 \mathrm{mg} / \mathrm{kg} \mathrm{VE}+$ $0 \mathrm{SeL}$; T3) corn + $0 \mathrm{VE}+0.3 \mathrm{ppm} \mathrm{SeL}$; T4) corn $+200 \mathrm{mg} / \mathrm{kg} \mathrm{VE}+0.3 \mathrm{ppm} \mathrm{SeL}$; T5) brown rice + $0 \mathrm{VE}+0 \mathrm{SeL}$; T6) brown rice $+200 \mathrm{mg} / \mathrm{kg} \mathrm{VE}+0$ $\mathrm{SeL}$; T7) brown rice $+0 \mathrm{VE}+0.3 \mathrm{ppm} \mathrm{SeL}$; and $\mathrm{T} 8$ ) brown rice $+200 \mathrm{mg} / \mathrm{kg} \mathrm{VE}+0.3 \mathrm{ppm} \mathrm{SeL}$.

The rice used was "BRS Querência," a long, light grain type, developed by EMBRAPA-CPACT 
Genetic Improvement Program, which was dried and dehulled in an industrial plant (SCHEIBLER et al., 2015).

The birds were mixed-sex flocks that were randomly distributed in the experimental units in a balanced way, so all boxes received three males and two females, forming the experimental unit.
The controls of temperature, ventilation and mortality were conducted daily during the experimental period. Meat quality was assessed using breast samples obtained only from male broilers, in accordance with the experimental diets listed in Table 1.

Table 1. Composition of experimental diets for broilers from 22-42 days old ( $\mathrm{kg} / \mathrm{ton})$.

\begin{tabular}{|c|c|c|c|c|c|c|c|c|}
\hline \multirow{2}{*}{ Ingredients (kg) } & \multicolumn{8}{|c|}{ Treatments } \\
\hline & T1 & $\mathrm{T} 2$ & T3 & T4 & T5 & T6 & T7 & T8 \\
\hline Corn & 643.68 & 643.68 & 643.68 & 643.68 & - & - & - & - \\
\hline Brown rice & - & - & - & - & 611.52 & 611.52 & 611.52 & 611.52 \\
\hline Soybean meal (44\%) & 280.8 & 280.8 & 280.8 & 280.8 & 289.43 & 289.43 & 289.43 & 289.43 \\
\hline Soybean oil & 38.31 & 38.31 & 38.31 & 38.31 & 62.37 & 62.37 & 62.37 & 62.37 \\
\hline Dicalcium phosphate & 15.00 & 15.00 & 15.00 & 15.00 & 16.52 & 16.52 & 16.52 & 16.52 \\
\hline Limestone & 12.37 & 12.37 & 12.37 & 12.37 & 11.11 & 11.11 & 11.11 & 11.11 \\
\hline Salt & 3.84 & 3.84 & 3.84 & 3.84 & 3.05 & 3.05 & 3.05 & 3.05 \\
\hline Premix* & 6.00 & 6.00 & 6.00 & 6.00 & 6.00 & 6.00 & 6.00 & 6.00 \\
\hline SeL “on top" (ppm) & - & - & 0.30 & 0.30 & - & - & 0.30 & 0.30 \\
\hline VE "on top" & - & 0.2 & - & 0.2 & - & 0.2 & - & 0.2 \\
\hline \multicolumn{9}{|l|}{ Calculated Nutrient composition } \\
\hline $\mathrm{ME}, \mathrm{kcal} / \mathrm{kg}$ & 3150 & 3150 & 3150 & 3150 & 3150 & 3150 & 3150 & 3150 \\
\hline Crude Protein \% & 17.6 & 17.6 & 17.6 & 17.6 & 17.6 & 17.6 & 17.6 & 17.6 \\
\hline Calcium \% & 0.90 & 0.90 & 0.90 & 0.90 & 0.90 & 0.90 & 0.90 & 0.90 \\
\hline Digestible Phosphorous (\%) & 0.38 & 0.38 & 0.38 & 0.38 & 0.38 & 0.38 & 0.38 & 0.38 \\
\hline Total Methionine+Cystine (\%) & 0.75 & 0.75 & 0.75 & 0.75 & 0.73 & 0.73 & 0.73 & 0.73 \\
\hline Total Methionine (\%) & 0.44 & 0.44 & 0.44 & 0.44 & 0.46 & 0.46 & 0.46 & 0.46 \\
\hline Total Lysine (\%) & 0.95 & 0.95 & 0.95 & 0.95 & 1.00 & 1.00 & 1.00 & 1.00 \\
\hline Total Choline (\%) & 1495 & 1495 & 1495 & 1495 & 1732 & 1732 & 1732 & 1732 \\
\hline Crude Fibre (\%) & 3.32 & 3.32 & 3.32 & 3.32 & 9.97 & 9.97 & 9.97 & 9.97 \\
\hline Total sodium (\%) & 0.18 & 0.18 & 0.18 & 0.18 & 0.18 & 0.18 & 0.18 & 0.18 \\
\hline
\end{tabular}

*(guaranteed levels/kg product): Vit. A 1440000 UI, Vit. E 2600 mg, Vit. D3 320000 UI, Vit. K3 280 mg, Vit. B1 360 mg, Vit. B2 1000 UI, Vit. B6 $600 \mathrm{mg}$, Vit. B12 $2400 \mathrm{mcg}$, niacin $7000 \mathrm{mg}$, folic acid $150 \mathrm{mg}$, pantothenic acid $2400 \mathrm{mg}$, methionine $240 \mathrm{~g}$, choline 60 g, manganese $20000 \mathrm{mg}$, zinc $12000 \mathrm{mg}$, iron $10000 \mathrm{mg}$, copper $1995 \mathrm{mg}$, iodine $120 \mathrm{mg}$, selenium $65 \mathrm{mg}$.

\section{Quantification of Se in meat}

The Se was quantified using hydride generation atomic absorption spectrometry (HGAAS).

After slaughter, samples of skinned broilers breast were kept at $4^{\circ} \mathrm{C}$ for $48 \mathrm{~h}$, then analysed for $\mathrm{pH}, \mathrm{WHC}$ and CL. Remaining samples were frozen at $-18^{\circ} \mathrm{C}$ and after 60 days of storage were thawed at $4{ }^{\circ} \mathrm{C}$ before evaluation of Se, DL and colour.

\section{Instrumental analysis of meat}

For instrumental analysis, four breasts were randomly selected from each treatment group, totalling 20 samples, which were identified and frozen at $-20^{\circ} \mathrm{C}$ until analysis. The samples were thawed for $24 \mathrm{~h}$ at $4^{\circ} \mathrm{C}$. The thawed, deboned breasts were separated and the right fillets of the raw breast were analysed as described below. 
The $\mathrm{pH}$ was measured using a digital $\mathrm{pH}$ meter (Marte MB 10) with direct insertion of the electrode in the breast muscle $\left(10^{\circ} \mathrm{C}\right)$.

Colour measurements (Minolta Chroma Meter CR-300, Osaka, Japan) were taken at three distinct sample points, using the CIELAB L*, a* and $\mathrm{b}^{*}$ parameters, where $\mathrm{L}^{*}=$ lightness, $\mathrm{a}^{*}=$ red-green component and $\mathrm{b}^{*}=$ yellow-blue component, to obtain an average value for the muscle (pectoralis major) colour. The $\mathrm{L}^{*}$ parameter or luminosity, ranges from zero (black) to 100 (white), while $\mathrm{a}^{*}$ varies from $\mathrm{a}^{*}>0$ (red) to $\mathrm{a}^{*}<0$ (green), and $\mathrm{b}^{*}$ varies from $b^{*}>0$ (yellow) to $b^{*}<0$ (blue) (LEMES et al., 2014).

The WHC was evaluated using the pressure method (SIERRA, 1973). Aliquots (5 g) of the ground meat samples were placed between two circular filter papers and received a pressure exerted by a weight of $2.25 \mathrm{~kg}$ for $5 \mathrm{~min}$. After this process, they were weighed again using a digital scale to calculate the water loss. The results were expressed as a percentage of water exuded, based on the initial sample weight.

For CL determination, the raw samples were weighed, wrapped in aluminium paper and grilled with an electric grill (Black \& Decker, Model SG 1600 , Brazil) until the internal temperature of the sample reached $85^{\circ} \mathrm{C}$. The results were expressed as a percentage of sample weight loss at ambient temperature (the difference between the initial and final weight of the samples corresponded to the water loss during cooking).

The DL was determined on aliquots $(5 \mathrm{~g})$ of raw samples that were taken from the pectoralis major using a $1 \mathrm{~cm}$ diameter probe at right angles to the muscle fibres.

The samples were conditioned at $4^{\circ} \mathrm{C}$ for 5 days in plastic tubes that allow dripping. The difference in weight corresponding to DL was expressed as a percentage of the initial weight of the sample (BERRI et al., 2008). Only the 1 st and 5th day of storage were used in the DL calculation.

\section{Statistical analysis}

The mathematical model used for statistical analysis of the results was Yijkl $=\mu+A i+\beta j+C k+$ $A \beta i j+A C i k+\beta C j k+(\mathrm{A} \beta C) i \mathrm{jk}+E i j k l$, where: Yijkl $=$ response variable in the repetition $1, \mathrm{k}$ of level $\mathrm{C}, \mathrm{j}$ of $\beta$ and level I of $\mathrm{A} ; \mu=$ general mean; $\mathrm{Ai}=$ effect of energy source $(i=1,2) ; \beta j=$ effect of vitamin $E$ $(j=1,2) ; C k=$ Effect of SeL $(k=1,2) ;(A \beta C) i j k=$ effect of interaction $\mathrm{A} \beta \mathrm{C}$ at level i, j, k; and Eijkl = random error.

Data were analysed by ANOVA with VE, SeL and cereal as fixed factors using the statistical package R (R CORE TEAM, 2015). The least squares means (LSM) was used to compare treatments. Multiple comparisons of treatment means were performed using orthogonal contrasts. A probability value of $\mathrm{P}<0.05$ was considered statistically significant.

\section{Results and Discussion}

\section{Quantification of Se in meat}

The influence of VE and SeL on Se deposition in the breast meat is presented in Table 2. The amount of $\mathrm{Se}$ in the chest was greater $(\mathrm{P}<0.0001)$ with the inclusion, in combination with $200 \mathrm{mg} / \mathrm{kg}$ of $\mathrm{VE}$ (Table 2). Conversely, only the 0.3 ppm SeL dietary supplementation did not significantly affect the recovery of $\mathrm{Se}$ in the meat $(\mathrm{P}=0.93)$.

A possible analytical error by the HGAAS method in the present study may explain the lower Se deposition in the muscle of birds receiving SeL compared to those receiving Se in the diets. This result contradicts earlier reports in the literature concerning poultry, pork, beef, eggs and milk (SURAI, 2006).

An interaction $(\mathrm{P}=0.06)$ between the inclusion of $\mathrm{VE}$ and SeL in the diet with the amount of Se recovered in the meat was found. This interaction can be explained because with the addition of VE in the diet increased in the breast meat, particularly in the presence of SeL. 
It is possible that the larger amount of Se found in the meat of the birds supplemented with VE than without VE, was due more to the sparing effect of avoiding depletion in the muscle than from the 21 day supplementation of SeL in the growth diet of broilers.

Table 2. Influence of vitamin E (VE) and selenium yeast (SeL) on selenium deposition (Se), water holding capacity (WHC) and cooking loss (CL) of pectoralis major in broilers fed corn- or brown rice-based diets.

\begin{tabular}{|c|c|c|c|c|c|c|c|}
\hline \multirow{3}{*}{ Cereal } & \multirow{3}{*}{$\begin{array}{c}\mathrm{VE} \\
(\mathrm{mg} / \mathrm{kg})\end{array}$} & & & \multicolumn{2}{|c|}{ Selenium yeast (ppm) } & \multirow[b]{2}{*}{$\mathbf{0}$} & \multirow[b]{2}{*}{0.3} \\
\hline & & $\mathbf{0}$ & 0.3 & $\begin{array}{c}\mathbf{0} \\
\end{array}$ & 0.3 & & \\
\hline & & \multicolumn{2}{|c|}{$\mathrm{Se}(\mathrm{mg} / \mathrm{kg})$} & \multicolumn{2}{|c|}{ WHC (\%) } & \multicolumn{2}{|c|}{ CL $(\%)$} \\
\hline \multirow[t]{2}{*}{ Corn } & $\mathbf{0}$ & 0.0394 & 0.0490 & 82.91 & 82.61 & 27.72 & 26.56 \\
\hline & 200 & 0.0782 & 0.1122 & 82.53 & 82.88 & 25.83 & 27.62 \\
\hline \multirow[t]{2}{*}{ Brown rice } & 0 & 0.0674 & 0.0264 & 80.18 & 83.62 & 28.16 & 28.13 \\
\hline & 200 & 0.1180 & 0.1184 & 83.17 & 83.01 & 27.97 & 27.07 \\
\hline \multicolumn{8}{|l|}{ Effect } \\
\hline \multicolumn{2}{|l|}{ SeL } & \multicolumn{2}{|r|}{0.93} & \multicolumn{2}{|c|}{0.20} & \multicolumn{2}{|c|}{0.92} \\
\hline \multicolumn{2}{|l|}{ VE } & \multicolumn{2}{|c|}{$<0.0001$} & \multicolumn{2}{|c|}{0.38} & \multicolumn{2}{|c|}{0.49} \\
\hline \multicolumn{2}{|l|}{ Cereal } & \multicolumn{2}{|c|}{0.14} & \multicolumn{2}{|c|}{0.71} & \multicolumn{2}{|c|}{0.24} \\
\hline \multicolumn{2}{|l|}{$\mathrm{VE} * \mathrm{SeL}$} & \multicolumn{2}{|r|}{0.06} & \multicolumn{2}{|c|}{0.26} & \multicolumn{2}{|c|}{0.49} \\
\hline \multicolumn{2}{|l|}{ Cereal*SeL } & \multicolumn{2}{|r|}{0.02} & \multicolumn{2}{|c|}{0.22} & \multicolumn{2}{|c|}{0.61} \\
\hline \multicolumn{2}{|l|}{ Cereal*VE } & \multicolumn{2}{|r|}{0.25} & \multicolumn{2}{|c|}{0.34} & \multicolumn{2}{|c|}{0.89} \\
\hline Cereal*VE* & & & 0.62 & & & & \\
\hline Contrasts & & & $(\mathrm{mg} / \mathrm{kg})$ & & $(\%)$ & & \\
\hline C1) T1 T2 T & s. T5 T6 T7 T8 & & 0.14 & & & & \\
\hline C2) T2 T6v & & & 0.001 & & & & \\
\hline C3) Т3 T7v & & & 0.001 & & & & \\
\hline C4) T5 vs. T & & & 0.14 & & & & \\
\hline C5) T1 vs. T & & & 0.006 & & & & \\
\hline
\end{tabular}

T1) corn + $0 \mathrm{SeL}+0 \mathrm{VE}$ (control); T2) corn + $200 \mathrm{mg} / \mathrm{kg} \mathrm{VE}+0 \mathrm{SeL}$; T3) corn + 0 VE + $0.3 \mathrm{ppm} \mathrm{SeL}$; T4) corn + $200 \mathrm{mg} / \mathrm{kg} \mathrm{VE}$ $+0.3 \mathrm{ppm}$ SeL; T5) brown rice + $0 \mathrm{VE}+0 \mathrm{SeL}$; T6) brown rice $+200 \mathrm{mg} / \mathrm{kg} \mathrm{VE}+0 \mathrm{SeL}$; T7) brown rice + $0 \mathrm{VE}+0.3 \mathrm{ppm} \mathrm{SeL}$; T8) brown rice $+200 \mathrm{mg} / \mathrm{kg} \mathrm{VE}+0.3 \mathrm{ppm} \mathrm{SeL}$.

C1) effect of replacing corn by grain brown rice. C2) supplementation of VE vs. SeL. C3) effect of supplementation of VE in combination with SeL. C4) effect of supplementation of SeL and/or VE in rice-based diets. C5) effect of supplementation of SeL and/or VE in corn-based diets.

In a literature review, Suchý et al. (2014) summarised the association between $\mathrm{VE}$ and $\mathrm{Se}$ in the sense that the VE spares the need of Se, indicating that it is possible to obtain a positive response on chicken yield indicators even if there is an insufficient amount of one of these two substances. According to the review, the need for Se decreases inversely to the VE levels, which proves the sparing effect of VE on the need for Se, or that the deficiency of Se increases the need for VE. Therefore, the relation between VE and SeL could be influencing the results of this experiment.
Couloigner et al. (2015) studied the kinetics of deposition of various Se sources on the chest muscle and feathers of broilers up to 21 days of age. These authors found that at 7 days of age, the amount of Se in the breast muscle decreased significantly by 15 and $37 \%$ compared to 1-day-old chicks supplemented with $0.2 \mathrm{mg} \mathrm{Se} / \mathrm{kg}$ in organic and inorganic form, respectively. The same authors also found that at 21 days of age, the amount of Se in the breast muscle remained the same as that at birth in birds fed SeL, while it decreased in birds supplemented with inorganic Se and in birds that 
were not supplemented. The reduction of Se in the breast muscle in that work could be explained in part by Se mobilisation in the muscle through protein turnover, releasing the selenomethionine from muscle proteins (COULOIGNER et al., 2015). Conversely, the rapid breast muscle growth between 14 and 21 days of age could also explain the slight reduction of Se in the breast in birds fed SeL (COULOIGNER et al., 2015).

O'Grady et al. (2001) found that the inclusion of dietary SeL, with or without the addition of VE, did not affect the muscle Se concentrations of beef cattle. According to the authors, a relatively high Se amount in the basal diets can reduce the effect of dietary supplementation with SeL. However, in our study, although the mineral and vitamin premix would supply the basic requirements of Se, it was expected that supplementation in addition to SeL could incorporate Se more easily into the meat, because selenomethionine takes the place of methionine in protein synthesis and is stored in the muscles and tissues of animals (SURAI, 2002).

Se is a trace element that is added to the diet in very small amounts in powder form, which, in some instances, may not be homogeneously mixed into the diet and this may cause excessive consumption in some animals and deficiencies in others (ZIAEI; POUR, 2013). This could be a possible alternative explanation for the lack of effect of SeL in the diets. Anyway, these results were not expected, as there are studies that confirm the possibility to enrich the meat with Se through SeL supplementation in the diet (CANTOR et al., 1982; PAYNE; SOUTHERN, 2005).

A significant interaction between corn and rice with the $\mathrm{SeL}$ inclusion was observed. In the corn-based diets, the SeL inclusion produced a Se increase in the meat, but the same result did not occur in the rice diets (Table 2). Using multiple contrasts of means, it was observed that the addition of VE compared to supplementation of SeL alone (T2 versus T3, T6 and T7) produced meat with higher amounts of Se (Table 2). This result indicates synergism between VE and Se.

The Se is involved in many physiological functions, including its association with GPx, which has antioxidant effects (PAYNE; SOUTHERN, 2005). The VE in the cell membrane and the Se as a GPx component, prevents peroxidation of cholesterol and fatty acids, thereby reducing the production of free radicals (SALMAN et al., 2007), which results in improved meat quality (ZIAEI; POUR, 2013). This suggests a synergistic interaction between VE and Se because GPx continues the antioxidant effect of VE (ZIAEI; POUR, 2013). Our results confirm this effect by contrast 3 (T3 T7 versus T4 T8), which analyses the influence of VE in combination with SeL supplementation. Adding VE in diets containing SeL, resulted in higher levels of Se in the meat.

Contrast 5 (T1 versus T2, T3 and T4), which examines the effect of SeL supplementation and/or VE in corn-based diets, also indicates that adding SeL and VE increases the levels of Se in the meat. Similar effects were not observed in the rice-based diets. Possibly these results can be explained by the greater amount of Se and VE present in brown rice compared to corn. This raises the possibility that the rice-based diets require less supplementary Se and VE. Furthermore, bioactive molecules with antioxidant activity have been reported in rice (TIAN et al., 2004; KIM et al., 2011), which may have influenced the higher content of $\mathrm{Se}$ in the meat of birds fed non-supplemented rice-based diets compared to non-supplemented corn-based diets.

\section{Instrumental analysis of meat}

The analysis of variance indicated that there was no significant effect of VE and SeL supplementation or corn replacement by brown rice in the diet, on the WHC and CL (Table 2). The results also indicated no double or triple significant interactions for these two response variables. The WHC is defined as the ability of the meat to retain water after treatment 
with external forces, such as heating, cutting, grinding and pressure (MUCHENJE et al., 2009). In this study, when the meat samples were treated by an external force, the effects of combined SeL and VE supplementation versus non-supplemented diets showed a higher WHC (Table 2) only in birds fed rice-based diets (T5 versus T6, T7 and T8).

Some factors that may influence the WHC, include the liquid electric charge of the myofibrillar proteins, the structure of muscle cells and their components (cytoskeleton, membrane permeability and myofibrils) and the amount of muscle extracellular space (HUFF-LONERGAN; LONERGAN, 2005). The $\mathrm{pH}$ of the post-mortem muscle also has a strong influence on meat quality, including the WHC and the colour (YOUNG et al., 2004). In general, the WHC of meat is closely related to the muscle $\mathrm{pH}$, and the higher the $\mathrm{pH}$, the higher the WHC of the meat (ZHANG; BARBUT, 2005; BERRI et al., 2008). Furthermore, there is a strong correlation between low $\mathrm{pH}$ and the paleness of breast muscle (FLETCHER, 1999) and low WHC (DRANSFIELD; SOSNICKI, 1999).

During the conversion of muscle to meat, lactic acid is formed in tissues, leading to a decrease in $\mathrm{pH}$ of the meat. When the $\mathrm{pH}$ reaches the isoelectric point of the muscle proteins $(\mathrm{pI}=5.4)$, the proteins, particularly myosin, have the same number of positive and negative charges. These positive and negative charges are attracted to each other, resulting in a reduction in the amount of water that can be retained by muscle protein given that water is a dipolar molecule that is attracted to electrically charged substances (HUFF-LONERGAN;
LONERGAN, 2005; RUIZ-RAMÍREZ et al., 2005).

However, this hypothesis was not fully established in this study, because there were no significant differences between the best WHC in the rice-based diets (T5 versus T6, T7 and T8) and $\mathrm{pH}$ and meat colour.

Although the experimental diets were isocaloric in this study, the rice-based diets contained twice the amount of oil compared to the corn-based diet (Table 1). Possibly, this difference also influenced the fat composition of the meat and, consequently, the WHC. According to Lemes et al. (2014), WHC has a high correlation with the amount of fat, which results in reduced water loss.

The results presented in Table 3 show that none of the factors analysed individually influenced DL (without the use of an external force). Furthermore, there was no interaction between the factors studied. The evaluation of multiple contrasts of means demonstrated that DL was not affected by the treatments (Table 3). These results disagree with those of Choct et al. (2004), who observed that birds fed SeL showed a reduction in DL.

In Table 4, the contrast 2 (T2 and T6 versus T3 and T7), shows that supplementation with SeL produced meat with higher $\mathrm{pH}$, compared to supplementation with VE, without affecting the colour or DL. Birds fed SeL showed higher $\mathrm{pH}$ values on the first day of evaluation ( $\mathrm{P}=0.001)$. Moreover, the inclusion of $\mathrm{VE}$ and the replacement of corn by brown rice did not alter the $\mathrm{pH}$ of the meat. There was no interaction between SeL, VE and replacing corn with brown rice on the $\mathrm{pH}$ of the meat. 
Table 3. Influence of vitamin E (VE) and selenium yeast (SeL) on drip loss (DL) (\%) of pectoralis major in broilers fed corn- or brown rice-based diets.

\begin{tabular}{|c|c|c|c|c|c|}
\hline \multirow{3}{*}{ Cereal } & \multirow{3}{*}{$\begin{array}{c}\mathrm{VE} \\
(\mathrm{mg} / \mathrm{kg})\end{array}$} & \multicolumn{4}{|c|}{ Selenium yeast $(\mathrm{ppm})$} \\
\hline & & $\mathbf{0}$ & 0.3 & $\mathbf{0}$ & 0.3 \\
\hline & & \multicolumn{2}{|c|}{ Day 1} & \multicolumn{2}{|c|}{ Day 5} \\
\hline \multirow[t]{2}{*}{ Corn } & $\mathbf{0}$ & 6.09 & 5.46 & 8.85 & 8.11 \\
\hline & 200 & 4.29 & 5.98 & 7.80 & 9.33 \\
\hline \multirow[t]{2}{*}{ Brown rice } & $\mathbf{0}$ & 6.68 & 5.51 & 9.92 & 9.90 \\
\hline & 200 & 5.47 & 4.76 & 8.51 & 8.80 \\
\hline \multicolumn{2}{|l|}{ Effect } & \multicolumn{4}{|c|}{ P-value } \\
\hline \multicolumn{2}{|l|}{ SeL } & \multicolumn{2}{|r|}{0.78} & \multicolumn{2}{|c|}{0.72} \\
\hline \multicolumn{2}{|l|}{ VE } & \multicolumn{2}{|r|}{0.28} & \multicolumn{2}{|c|}{0.43} \\
\hline \multicolumn{2}{|l|}{ Cereal } & \multicolumn{2}{|r|}{0.84} & \multicolumn{2}{|c|}{0.30} \\
\hline \multicolumn{2}{|l|}{ VE*SeL } & \multicolumn{2}{|r|}{0.35} & \multicolumn{2}{|c|}{0.38} \\
\hline \multicolumn{2}{|l|}{ Cereal*SeL } & \multicolumn{2}{|r|}{0.33} & \multicolumn{2}{|c|}{0.86} \\
\hline \multicolumn{2}{|c|}{ Cereal*VE } & \multicolumn{2}{|r|}{0.82} & \multicolumn{2}{|c|}{0.36} \\
\hline \multicolumn{2}{|c|}{ Cereal*VE*SeL } & \multicolumn{2}{|r|}{0.53} & \multicolumn{2}{|c|}{0.50} \\
\hline \multicolumn{6}{|c|}{ Contrasts } \\
\hline \multicolumn{2}{|c|}{ C1) T1 T2 T3 T4 vs. T5 T6 T7 T8 } & \multicolumn{2}{|r|}{0.84} & \multicolumn{2}{|c|}{0.30} \\
\hline \multicolumn{2}{|c|}{ C2) T2 T6 vs. T3 T7 } & \multicolumn{2}{|r|}{0.58} & & \\
\hline C3) Т3 T7 v & & & 0.92 & & \\
\hline C4) T5 vs. T & & & 0.24 & & \\
\hline C5) T1 vs. T & & & 0.48 & & \\
\hline
\end{tabular}

T1) corn + 0 SeL + 0 VE (control); T2) corn + $200 \mathrm{mg} / \mathrm{kg} \mathrm{VE} \mathrm{+} 0$ SeL; T3) corn + 0 VE + $0.3 \mathrm{ppm} \mathrm{SeL}$; T4) corn + $200 \mathrm{mg} / \mathrm{kg} \mathrm{VE}$ + $0.3 \mathrm{ppm} \mathrm{SeL}$; T5) brown rice + $0 \mathrm{VE}+0 \mathrm{SeL}$; T6) brown rice + $200 \mathrm{mg} / \mathrm{kg}$ VE + 0 SeL; T7) brown rice + 0 VE + $0.3 \mathrm{ppm}$ SeL; T8) brown rice $+200 \mathrm{mg} / \mathrm{kg} \mathrm{VE}+0.3 \mathrm{ppm} \mathrm{SeL}$.

C1) effect of replacing corn by grain brown rice. C2) supplementation of VE vs. SeL. C3) effect of supplementation of VE in combination with SeL. C4) effect of supplementation of SeL and/or VE in rice-based diets. C5) effect of supplementation of SeL and/or VE in corn-based diets.

Table 4 shows that the substitution of corn with brown rice in the diets, influenced the $\mathrm{L}^{*}(\mathrm{P}=0.05)$, $\mathrm{a}^{*}(\mathrm{P}=0.01)$ and $\mathrm{b}^{*}(\mathrm{P}<0.0001)$ colour parameters of the meat. A triple interaction for the $b^{*}$ value was observed. In corn-based diets supplemented with the SeL and VE combination, there was a decrease in $b^{*}$ value, while in rice-based diets this response was not observed. This triple interaction besides not being expected is difficult to explain. Therefore, these results indicate that further studies are needed to understand the physiology of pigment deposition in the skin of chickens in the presence or absence of SeL and VE in the diet.
No other variable was affected. However, in diets with rice all $b^{*}$ values were low. When all diets with corn were compared against the rice-based diets ( $\mathrm{T} 1$, T2, T3 and T4 versus T5, T6, T7 and T8), a trend in the $\mathrm{L}^{*}$ scale and a highly significant difference in the $\mathrm{b}^{*}$ scale $(\mathrm{P}<0.0001)$ was evident, as seen in Figure 1. Compared to corn-based diets, rice-based diets reduce skin pigmentation but do not influence the nutritional value of the meat to the consumer. Moreover, natural and synthetic pigments can be added to the diet if needed. 
Table 4. Influence of vitamin $\mathrm{E}(\mathrm{VE})$ and selenium yeast $(\mathrm{SeL})$ on $\mathrm{pH}$ and colour of the pectoralis major in broilers fed corn- or brown rice-based diets.

\begin{tabular}{|c|c|c|c|c|c|c|c|c|c|c|c|}
\hline \multirow{4}{*}{ Cereal } & \multirow{4}{*}{$\begin{array}{c}\mathrm{VE} \\
(\mathrm{mg} / \mathrm{kg})\end{array}$} & \multicolumn{10}{|c|}{ Selenium yeast $(\mathrm{ppm})$} \\
\hline & & $\mathbf{0}$ & 0.3 & $\mathbf{0}$ & 0.3 & $\mathbf{0}$ & 0.3 & $\mathbf{0}$ & 0.3 & $\mathbf{0}$ & 0.3 \\
\hline & & \multirow{2}{*}{\multicolumn{2}{|c|}{ pH Day 1}} & \multirow{2}{*}{\multicolumn{2}{|c|}{ pH Day 5}} & \multicolumn{6}{|c|}{ Colour } \\
\hline & & & & & & \multicolumn{2}{|c|}{$\mathrm{L}^{*}$} & \multicolumn{2}{|c|}{$\mathrm{a}^{*}$} & \multicolumn{2}{|c|}{$\mathrm{b}^{*}$} \\
\hline \multirow[t]{2}{*}{ Corn } & $\mathbf{0}$ & 5.93 & 5.97 & 6.07 & 6.08 & 50.2 & 48.1 & 4.3 & 4.8 & 5.0 & 6.1 \\
\hline & 200 & 5.91 & 5.99 & 6.02 & 6.08 & 48.7 & 48.2 & 5.3 & 5.0 & 6.3 & 3.8 \\
\hline \multirow[t]{2}{*}{ Rice } & $\mathbf{0}$ & 5.90 & 6.05 & 6.06 & 6.12 & 51.5 & 49.6 & 5.7 & 5.9 & 0.5 & 0.3 \\
\hline & 200 & 5.89 & 5.97 & 6.08 & 6.17 & 49.9 & 49.9 & 5.6 & 5.9 & 1.4 & 1.3 \\
\hline \multicolumn{4}{|l|}{ Effect } & \multicolumn{8}{|c|}{ P-value } \\
\hline \multicolumn{2}{|l|}{$\mathrm{SeL}$} & & & 0.01 & 0.05 & \multicolumn{2}{|c|}{0.12} & \multicolumn{2}{|r|}{0.58} & \multicolumn{2}{|c|}{0.28} \\
\hline \multicolumn{2}{|l|}{ VE } & & & 0.59 & 0.89 & \multicolumn{2}{|r|}{0.38} & \multicolumn{2}{|r|}{0.49} & \multicolumn{2}{|c|}{0.59} \\
\hline \multicolumn{2}{|l|}{ Cereal } & & & 0.87 & 0.14 & \multicolumn{2}{|r|}{0.05} & \multicolumn{2}{|r|}{0.01} & \multicolumn{2}{|c|}{$<0.0001$} \\
\hline \multicolumn{2}{|c|}{$\mathrm{VE}^{*} \mathrm{SeL}$} & & & 0.84 & 0.49 & \multicolumn{2}{|r|}{0.25} & & 0.64 & & 3 \\
\hline Cereal* & SeL & & & 0.44 & 0.44 & & 0.81 & & 0.88 & & 14 \\
\hline Cereal* & & & & 0.42 & 0.31 & & 0.90 & & 0.35 & & 7 \\
\hline Cereal* & $V E * S e L$ & & & 0.35 & 0.87 & & 0.89 & & 0.56 & & 3 \\
\hline Contras & & & & & & & & & & & \\
\hline C1) T1 & Г2 T3 T4 & 5 T6 T7 T8 & & 0.87 & 0.14 & & 0.09 & & 0.10 & & 01 \\
\hline C2) $\mathrm{T} 2$ & Г6 vs. Т3 & & & 0.03 & 0.20 & & 0.55 & & 0.88 & & 91 \\
\hline C3) T3 & $\Gamma 7 v s . \mathrm{T} 4$ & & & 0.60 & 0.57 & & 0.90 & & 0.22 & & 47 \\
\hline C4) T5 & s. T6 T7 & & & 0.19 & 0.17 & & 0.74 & & 0.42 & & 52 \\
\hline C5) $\mathrm{T} 1 \mathrm{I}$ & $s . \mathrm{T} 2 \mathrm{~T} 3$ & & & 0.56 & 0.82 & & 0.18 & & 0.92 & & 49 \\
\hline
\end{tabular}

T1) corn + $0 \mathrm{SeL}+0 \mathrm{VE}$ (control); T2) corn + $200 \mathrm{mg} / \mathrm{kg} \mathrm{VE}+0 \mathrm{SeL}$; T3) corn + $0 \mathrm{VE}+0.3 \mathrm{ppm} \mathrm{SeL}$; T4) corn + $200 \mathrm{mg} / \mathrm{kg} \mathrm{VE}$ $+0.3 \mathrm{ppm} \mathrm{SeL}$; T5) brown rice + $0 \mathrm{VE}+0 \mathrm{SeL}$; T6) brown rice + $200 \mathrm{mg} / \mathrm{kg} \mathrm{VE}+0 \mathrm{SeL}$; T7) brown rice + $0 \mathrm{VE}+0.3 \mathrm{ppm}$ SeL; T8) brown rice $+200 \mathrm{mg} / \mathrm{kg} \mathrm{VE}+0.3 \mathrm{ppm} \mathrm{SeL}$.

C1) effect of replacing corn by grain brown rice. C2) supplementation of VE vs. SeL. C3) effect of supplementation of VE in combination with SeL. C4) effect of supplementation of SeL and/or VE in rice-based diets. C5) effect of supplementation of SeL and/or VE in corn-based diets.

Figure 1. Colour of the skin in broilers fed corn-based diets (left) and brown rice-based diets (right) throughout 21-42 days of age.

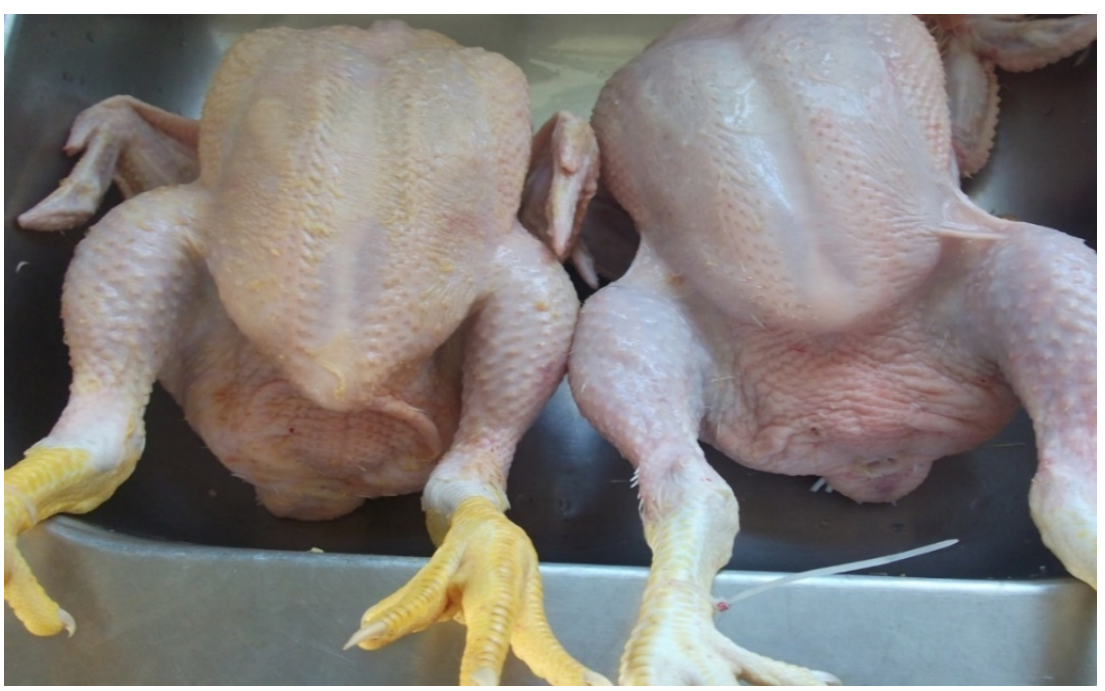


It was concluded that corn can be replaced completely by brown rice in the diet of broilers without major changes in the breast meat characteristics, except for the colour intensity, which reduces significantly. The interaction of VE and $\mathrm{SeL}$ in diets formulated with rice, increased the Se content and the WHC in the breast muscle of birds, without influencing the DL and CL.

\section{References}

AJUYAH, A. O.; AHN, D. U.; HARDIN, R. T.; SIM, J. S. Dietary antioxidants and storage affect chemical characteristics of $\omega-3$ fatty acid enriched broiler chicken meats. Journal of Food Science, Malden, v. 58, n. 1, p. 43-46, 1993.

BARROETA, A. C.; BAUCELlS, M. D.; CASTRO, A. Nutrición vitamínica óptima en ponedoras. In: BARROETA, A.; CALSAMIGLIA, S.; CEPERO, R.; LOPEZ, B. C.; HERNÁNDEZ, J. M. Óptima nutrición vitamínica de los animales para la producción de alimentos de calidad: avances en la nutrición vitamínica de broilers y pavos. Barcelona: Ed. España Pulso, 2002. p. $133-167$.

BERRI, C.; BESNARD, J.; RELANDEAU, C. Increasing dietary lysine increases final $\mathrm{pH}$ and decreases drip loss of broiler breast meat. Poultry Science, Savoy, v. 87, n. 3, p. 480-484, 2008.

BOU, R.; CODONY, R.; TRES, A.; DECKER, E. A.; GUARDIOLA, F. Dietary strategies to improve nutritional value, oxidative stability, and sensory properties of poultry products. Critical Reviews in Food Science and Nutrition, London, v. 49, n. 9, p. 800-822, 2009.

BUCKLEY, D. J.; MORRISSEY, P. A.; GRAY, J. I. Influence of dietary vitamin $\mathrm{E}$ on the oxidative stability and quality of pig meat. Journal of Animal Science, Champaign, v. 73, n. 10, p. 3122-3130, 1995.

CANTOR, A. H.; MOORHEAD, P. D.; MUSSER, M. A. Comparative effects of sodium selenite and selenomethionine upon nutritional muscular dystrophy, selenium-dependent glutathione peroxidase, and tissue selenium concentrations of turkey poults. Poultry Science, Savoy, v. 61, n. 3, p. 478-484, 1982.

CHOCT, M.; NAYLOR, A. J.; REINKE, N. Selenium supplementation affects broiler growth performance, meat yield and feather coverage. British Poultry Science, Berlin, v. 45, n. 5, p. 677-683, 2004.

COMINETTI, C.; BORTOLI, M. C.; ABDALLA, D. S. P.; COZZOLINO, S. M. F. Estresse oxidativo, selênio e nutrigenética. Nutrire: Revista Sociedade Brasileira de
Alimentação e Nutrição, São Paulo, v. 36, n. 3, p. 131153, 2011.

COULOIGNER, F.; JLALI, M.; BRIENS, M.; ROUFFINEAU, F.; GERAERT, P. A.; MERCIER, Y. Selenium deposition kinetics of different selenium sources in muscle and feathers of broilers. Poultry Science, Savoy, v. 94, n. 11, p. 2708-2714, 2015.

DRANSFIELD, E.; SOSNICKI, A. A. Relationship between muscle growth and poultry meat quality. Poultry Science, Savoy, v. 78, n. 5, p. 743-746, 1999.

FAUSTMAN, C.; CHAN, W. K.; SCHAEFER, D. M.; HAVENS, A. Beef color update: the role for vitamin E. Journal of Animal Science, Champaign, v. 76, n. 4, p. 1019-1026, 1998.

FLETCHER, D. L. Broiler breast meat color variation, pH, and texture. Poultry Science, Savoy, v. 78, n. 9, p. 1323-1327, 1999.

HUFF-LONERGAN, E.; LONERGAN, S. M. Mechanisms of water-holding capacity of meat: the role of postmortem biochemical and structural changes. Meat Science, Barking, v. 71, n. 1, p. 194-204, 2005.

KIEFER, C.; QUADROS, A. R. B. Avaliação técnicoeconômica da substituição do milho pela quirera de arroz em dietas de suínos. Revista Ceres, Viçosa, MG, v. 53, n. 305, p. 31-37, 2006.

KIM, D. J.; OH, S. K.; YOON, M. R.; CHUN, A.; CHOI, I. S.; LEE, D. H.; LEE, J. S.; YU, K. W.; KIM, Y. K. The change in biological activities of brown rice and germinated brown rice. Journal of the Korean Society of Food Science and Nutrition, Busanjin-gu, v. 40, n. 6, p. 781-789, 2011

LAWRIE, R. A. Ciência da carne. Tradução de Jane Maria Rubensam. 6. ed. Porto Alegre: Artmed, 2005. 384 p.

LEMES, J. S.; OSÓRIO, M. T. M.; OSÓRIO, J. C. S.; GONZAGA, S. S.; MARTINS, L. S.; ESTEVES, R. M. G.; LEHMEN, R. I. Características da carcaça e da carne de cordeiros Corriedale manejados em duas alturas de milheto. Archivos de Zootecnia, Córdoba, v. 63, n. 241, p. 161-170, 2014.

MAHAN, D. C.; KIM, Y. Y. The role of vitamins and minerals in the production of high quality pork. Asian Australasian Journal of Animal Science, Champaign, v. 12, n. 2, p. 287-294, 1999.

MONTE, A. L. S.; GONSALVES, H. R. O.; VILLARROEL, A. B. S.; DAMACENO, M. N.; CAVALCANTE, A. B. D. Qualidade da carne de caprinos e ovinos: uma revisão. Revista Agropecuária Científica no Semiárido, Campina Grande, v. 8, n. 3, p. 11-17, 2012.

MORENO, G. M. B.; LOUREIRO, C. M. B.; SOUZA, H. B. A. Características qualitativas da carne ovina. Revista Nacional da Carne, São Paulo, v. 1, n. 381, p. 76-90, 2008. 
MORRISSEY, P. A.; BUCKLEY, D. J.; SHEEHY, P. J. A.; MONAHAN, F. J. Vitamin E and meat quality. Proceedings of the Nutrition Society, London, v. 53, n. 2, p. 289-295, 1994.

MORRISSEY, P. A.; SHEEHY, P. J. A.; GALVIN, K.; KERRY, J. P.; BUCKLEY, D. J. Lipid stability in meat and meat products. Meat Science, Barking, v. 49, p. S73-S86, 1998. Supplement 1.

MUCHENJE, V.; DZAMA, K.; CHIMONYO, M.; STRYDOM, P. E.; HUGO, A; RAATS, J. G. Some biochemical aspects pertaining to beef eating quality and consumer health: a review. Food Chemistry, London, v. 112, n. 2, p. 279-289, 2009.

NATIONAL RESEARCH COUNCIL - NRC. Nutrient requirements of poultry. $9^{\text {th }}$ revised ed. Washington: National Academy Press, 1994.

O'GRADY, M. N.; MONAHAN, F. J.; FALLON, R. J.; ALLEN, P. Effects of dietary supplementation with vitamin $\mathrm{E}$ and organic selenium on the oxidative stability of beef. Journal of Animal Science, Champaign, v. 79, n. 11, p. 2827-2834, 2001.

PARDI, M. C.; SANTOS, I. F.; SOUZA, E. R.; PARDI, H. S. Ciência, higiene e tecnologia da carne. 2. ed. Goiânia: Universidade Federal de Goiânia, 2001. 623 p.

PAYNE, R. L.; SOUTHERN, L. L. Comparison of inorganic and organic selenium sources for broilers. Poultry Science, Savoy, v. 84, n. 6, p. 898-902, 2005.

$\mathrm{R}$ CORE TEAM - R. A language and environment for statistical computing. R Foundation for Statistical Computing. Vienna, 2015. Available at: $<\mathrm{https}$ ://www. Rproject.org>. Accessed at: 18 maio 2016.

ROLL, A. A. P.; HOBUSS, C. B.; DEL PINO, F. A. B.; ROLL, V. F. B.; DIONELLO, N. J. L.; XAVIER, E. G.; RUTZ, F. Óleo de canola e selênio orgânico na dieta de codornas: perfil de ácidos graxos, colesterol e qualidade de ovos. Semina: Ciências Agrárias, Londrina, v. 37, n. 1, p. 405-414, 2016.

RUIZ-RAMÍREZ, J.; ARNAU, J.; SERRA, X.; GOU, P. Relationship between water content, $\mathrm{NaCl}$ content, $\mathrm{pH}$ and texture parameters in dry-cured muscles. Meat Science, Barking, v. 71, n. 4, p. 579-587, 2005.

SALMAN, M.; SELÇUK, Z.; ÖHAKAN, M. Effect of vitamin $\mathrm{E}$ and selenium on performance, plasma and tissue Gsh-Px activity in broilers. Journal of Istanbul Veterinary Science, Istanbul, v. 1, n. 3, p. 25-34, 2007.

SAÑUDO, C.; SANCHEZ, A.; ALFONSO, M. Small ruminant production systems and factors affecting lamb meat quality. Meat Science, Barking, v. 49, n. 1, p. 29-64, 1998.

SCHEIBLER, R. B.; SCHAFHÄUSER, J.; RIZZO, F. A.; NÖRNBERG, J. L.; VARGAS, D. P.; SILVA, J. L. S.; FLUCK, A. C.; FIOREZE, V. I. Replacement of corn grain by brown rice grain in dairy cow rations: nutritional and productive effects. Animal Feed Science and Technology, New York, v. 208, n. 1, p. 214-219, 2015.

SENADO FEDERAL - Projeto de Lei do Senado $n^{\circ}$ 613, 2015. Brasília: Agenda Brasil 2015. Disponível em: $<$ http://www.senado.gov.br/atividade/materia/getPDF. asp?t=178398\&tp=1>. Acesso em: 16 ago. 2016.

SIERRA, I. Producción de cordero joven y pesado en la raza Raza Aragoneza. Zaragoza: Trabajos del I.E.P.G.E., 1973. n. 18, 28 p.

SILVA SOBRINHO, A. G. Aspectos quantitativos e qualitativos da produção de carne ovina. In: REUNIÃO ANUAL DA SOCIEDADE BRASILEIRA DE ZOOTECNIA, 38., 2001, Piracicaba. Anais... Piracicaba: Sociedade Brasileira de Zootecnia, 2001. p. 425-446.

SUCHÝ, P.; STRAKOVÁ, E.; HERZIG, I. Selenium in poultry nutrition: a review. Czech Journal of Animal Science, Prague, v. 59, n. 11, p. 495-503, 2014.

SUMMIT AGRICULTURAL GROUP. Summit agricultural group leads the way with state-of the-art. Brazil corn ethanol plant. Alden, 2016. Available at: $<$ http://summitag.com/wp-content/uploads/2016/03/ Summit-Brazil-Ethanol-Plant-4.5.2016.pdf $>$. Accessed at: 16 ago. 2016

SURAI, P. F. Natural antioxidants in avian nutrition and reproduction. Bath: Nottingham University Press, England, 2002. $615 \mathrm{p}$.

SURAI, P. F. Selenium in nutrition and health. Nottingham: Nottingham University Press, 2006. 974 p.

TIAN, S.; NAKAMURA, K.; KAYAHARA, H. Analysis of phenolic compounds in white rice, brown rice, and germinated brown rice. Journal of Agricultural and Food Chemistry, London, v. 52, n. 15, p. 4808-4813, 2004.

YOUNG, J. F.; KARLSSON, A. H.; HENCKEL, P. Waterholding capacity in chicken breast muscle is enhanced by pyruvate and reduced by creatine supplements. Poultry Science, Savoy, v. 83, n. 3, p. 400-405, 2004.

ZEOLA, N. M. B. L.; SOUZA, P. A.; SOUZA, H. B. A.; SILVA SOBRINHO, A. G.; BARBOSA, J. C. Cor, capacidade de retenção de água e maciez da carne de cordeiro maturada e injetada com cloreto de cálcio. Arquivo Brasileiro de Medicina Veterinária e Zootecnia, Belo Horizonte, v. 59, n. 4, p. 1058-1066, 2007.

ZHANG, L.; BARBUT, S. Rheological characteristics of fresh and frozen PSE, normal and DFD chicken breast meat. British Poultry Science, Edinburgh, v. 46, n. 6, p. 687-693, 2005.

ZIAEI, N.; POUR, E. E. The effects of different levels of vitamin-E and organic selenium on performance and immune response of laying hens. African Journal of Biotechnology, Nairobi, v. 12, n. 24, p. 3884-3890, 2013. 